\title{
六脚ロボット COMET-IIIの予見スライディングモード歩行制御*
}

\author{
池 戸洋 介*1, 野 波 健 蔵*2
}

\section{Preview Sliding Mode Walking Control for Hexapod Robot COMET-III}

\author{
Yosuke IKEDA and Kenzo NONAMI*3 \\ ${ }^{* 3}$ Faculty of Engineering, Chiba University, \\ 1-33 Yayoi-cho, Inage-ku, Chiba-shi, Chiba, 2638522 Japan
}

\begin{abstract}
The mine detection hexapod robot COMET-III is driven by hydraulic power. Because of the strong nonlinear characteristic of the oil pressure system, conventional classic methods produce the flattery delay to the target orbit. In the unknown environment of minefield, the robot leg must follow correctly the walking orbit. The sliding mode control has strong robustness to parameter change or disturbance, and the preview control prevents the flattery delay by using a future target value. In this paper, we design a preview sliding mode controller, which incorporate the advantages of both control theory, and so improves control performance.
\end{abstract}

Key Words : Humanitarian Deminig, Hexapod Robot, Walking Robot COMET - III, Preview Control, Sliding Mode Control, Hydraulic Power

\section{1. 緒言}

現在, 全世界には 1 億個以上もの地雷が埋設されて おり, 国際赤十字の調べでは, 毎日約 70 人，つまり 20 分間に 1 人が地雷の犠牲となっている.犠牲者の多く は農業, 牧畜などの体を使って労働に従事する人々で あり，障害者になることは，働けなくなることを意味 する，障害者に対する偏見が根深い社会も多く，犠牲 者は生涯二重三重の苦しみを受けつづけることにな る. 兵器製造の技術が進み, 1 個 3 米ドル (約 400 円) 程度の安さで生産され, ハイテク技術によって1分間 に 1000 個以上もが散布されてきた地雷. それを撤去 するには, ほとんど $100 \%$ 手作業によっているのが現 状である. 年間約 10 万個の地雷が撤去されているが, 5000 個の除去につき 1 人の死者と 2 人の負傷者, つ まり年間 60 名以上が除去作業中に実際犠牲になって いるのが現状である.

著者らの研究グループは, このような問題を解決す るための手段として, 危険な埋設地雷等の探知, 処理

\footnotetext{
* 原稿受付 2004 年 3 月 5 日.

*1 千葉大学自然科学研究科 (263-8522 千葉市稲毛区弥生町 1-33).

*2 正員, 千葉大学工学部.

E-mail : nonami@faculty.chiba-u.jp
}

作業を無人化して上記のような人的・経済的被害をな くすため, 歩行ロボットによる探知と処理を提案して きた(1)(2). 歩行ロボットは移動効率においては車輪形 などと比べて劣るものの, 安定かつ安全な着地点を離 散的に選択できるという点で地雷探知・処理作業に極 めて適しており, 地雷原における地雷や危険物の回避 歩行を実現できるという特徵を持っている．静的安定 性, 機動性などを考えた結果, 六脚歩行形式を採用し た地雷探知ロボットCOMET-I, IIによる研究を 1998 年より行ってきた. そして, これらのロボットに よる要素技術の開発の成果を基礎として, 実証機レべ ルの地雷探知ロボット COMET-IIIを製作した。本ロ ボットは六脚に 2 本のマニピュレー夕を有し, 歩行用 としてクローラを有している. COMET-I, II との 大きな違いは, 電気駆動方式から油圧駆動方式となり, 自律歩行が可能となっただけではなく, 速度向上とパ ワー不足の改善を䘕った。

ロボットの歩行方法としては目標軌道を算出し、そ の軌道に追従するようなサーボ系を構成しており,こ れまで各脚の位置決め制御には設計の容易さから PD 制御を用いてきた。しかしながら, 油圧駆動に起因す る問題を多く抱えており、油温の変化, 気泡の混入, 作動圧力の変化等によりシステムのパラメータが非線 
形的に変化することによって，良好な歩行制御が行え ていなかった。スライディングモード制御は，フィー ドバックゲインの高速切換によってシステムの状態を 切換超平面に拘束させ，その面に沿って原点に収束さ せる制御である.システムの挙動は切換面の特性のみ に支配されるので, パラメータ変動や外乱に対して極 めて強いロバスト性を有し, 油空圧システムの位置制 御系において大変効果がある(3)(4). しかし，フィード バック補償だけではアクチュエータに飽和が起こり， かつ, 時間遅れなどにより定常偏差が残ってしまう。 地雷原において, ロボットの自律歩行を実現させるた めに欠かすことのできない要素として，末知環境にお いて，オペレータが意図する歩行軌道に正確に追従す る必要があることから, 最適制御系に目標值の予見フ イードフォワード補償を付加することで, 応答を改善 させる予見制御(5)に着目した. そこで本報では，双方 の長所を取り入れることで優れた制御性能を有する予 見スライディングモード制御系(6) (PSMC)を設計し, 制御性能を改善させることにより安定した歩行を実現 させた。

文献 ( 6 )では予見スライディングモード制御の理論

Table 1 Hardware specification of COMET-III

\begin{tabular}{ll}
\hline Hydraulic Pump & $140 \mathrm{~kg} / \mathrm{cm}^{2}, 17 \mathrm{~L} / \mathrm{min}$ \\
Engine & 653cc, Max Output 22ps/3600rpm \\
& Max Torque 4.65kgm \\
Material & Aluminium Alloy, SUS304 \\
Crawler & Rubber Crawler \\
Hydraulic Tank & $40 \mathrm{~L}$ \\
Gasoline Tank & $20 \mathrm{~L}$ \\
Control Valve & 26 \\
Thigh Cylinder & $\phi 25 \times 250 \mathrm{st}$, \\
& Max Speed $280 \mathrm{~mm} / \mathrm{s}$ \\
Shank Cylinder & $\phi 30 \times 175 \mathrm{st}$, \\
& Max Speed $300 \mathrm{~mm} / \mathrm{s}$ \\
Leg Turn & Max Angle $\pm 80 \mathrm{deg}, 69 \mathrm{deg} / \mathrm{s}$ \\
Weight & Frame+Crawler+Engine+Hydralic \\
& Unit=1000kg, Legs=32kg $\times 6$ \\
Computer & SH4 (Clock frequency 198MHz) $\times 3$ \\
\hline
\end{tabular}

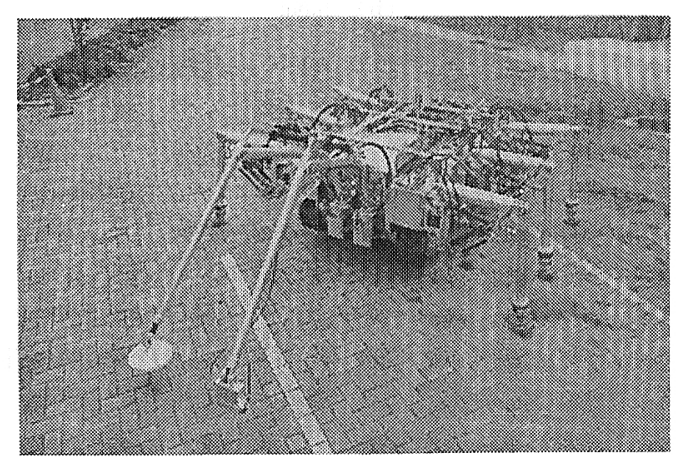

Fig. 1 Overview of COMET-III
的提案がなされているが，その有効性はシミュレーシ ヨンにとどまっている，本報では，実システムの六脚 歩行ロボットにこの方法を適用し, さらに, 著者らが 提案しているチャタリングのない離散時間スライディ ングモード法により設計することで有効性を検証して いるところに特徴がある.また, 歩行制御は各リング ごとの制御系設計で十分であることを明らかにしてい る.

\section{COMET-IIIとモデリング}

本報で制御対象となる地雷探知六脚歩行ロボット COMET-IIIを図 1 に, また, そのスペックを表 1 に示 す。脚部は 3 自由度を有し, 肩部は油圧モータにより 回転を行い，腿部・けい部については油圧シリンダに より駆動する.図 2 に示すように, ロボットの動作は シリンダ位置をポテンショメータにより計測し, A/D 変換を介して 32 ビットのコンピュータ $(\mathrm{HITACHI}$ 製：SH 4)により取り込み, 脚先の目標軌跡に対応す る各サーボ系の目標值を本ロボットの脚機構の逆運動 学から算出し,これに基づいて脚制御入力を計算す る。その計算された制御入力は, D/A 変㒜を介し, 比 例電磁弁のアンプに送られ, 弁のスプールを変位させ ることで可動部を動かす仕組みとなっている。

本報では, 油圧駆動システムが内在する多くの非線 形性や不確定性のため, 正確な数学モデルを理論的に 解析することは困難であると考えられることから，ア ンプ, バルブ, シリンダ系の開ループ特性を求めるの に際して,フィードバック系を構成して演算により制 御対象の伝達関数を求める。そこで各関節に比例制御 によるフィードバック系を付加し, 目標值から出力ま での伝達関数を獲得する。なお, 以下のような仮定を 基に同定を行う.

・関節軸まわりの慣性モーメントや重力等の影響は外

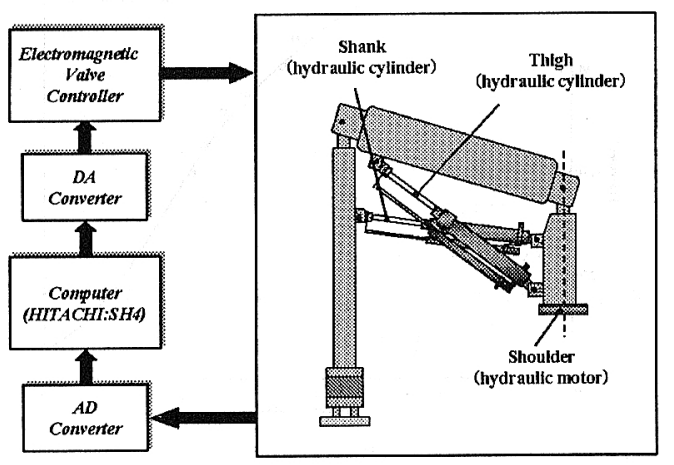

Fig. 2 Block diagram of controlled system 
乱とみなす。

・使用する片ロッド形のピストンの左右受圧面積は等 しいものとする.

・各脚の数学モデルは同一のものとする. モデルは式 (1)に示すような二次系にむだ時間システ ムを付加したものとなった。

$$
G(s)=\frac{\alpha \omega_{n}^{2}}{s^{2}+2 \zeta \omega_{n} s+\omega_{n}^{2}} \cdot \frac{1-\frac{1}{2} s T}{1+\frac{1}{2} s T} .
$$

ここでのむだ時間は油圧駆動システムの応答遅れであ り，一次の Padé近似によりモデルに取り入れてい

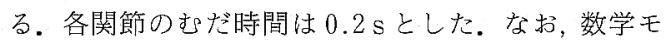
デルの算出は左前脚(leg 1)を対象としている，同定 方法はさまざまな周波数の正弦波を入力し，その出力

Table 2 Modeling parameters of leg 1

\begin{tabular}{c||c|c|c|c}
\hline & $\alpha$ & $\zeta$ & $\omega_{n}$ & $T$ \\
\hline Shoulder & 1.000 & 1.500 & 2.000 & 0.2 \\
\hline Thigh & 1.000 & 2.928 & 4.477 & 0.2 \\
\hline Shank & 1.000 & 3.028 & 5.507 & 0.2 \\
\hline
\end{tabular}

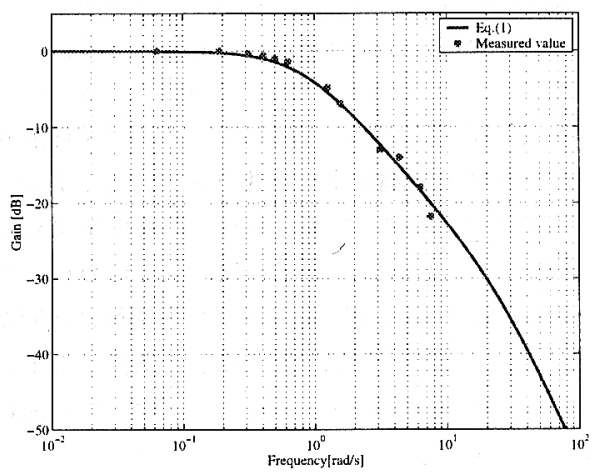

(a) Gain

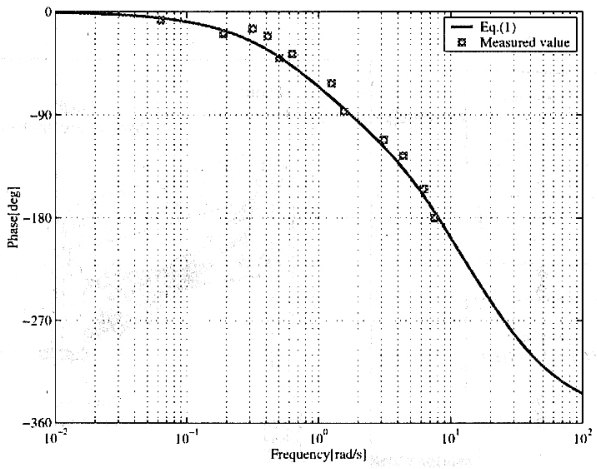

(b) Phase

Fig. 3 Bode plot of thigh
值との関係から実測值に合うようにパラメータ值を決 定した。表 2 に得られた各関節のパラメータ值を, 図 3 に腿部の目標值加出力までの周波数応答を示す. 整合性を確かめるため, 得られた伝達関数を用いたス テップ応答のシミュレーションと実験結果を図 4 亿示 す.図 4 よりここのモデルの出力と実際のモデルの出 力を比較し，ほ棌正確なモデルが得られたことがわか る. 同様な方法で肩部，けい部についても求めており， 良好な結果を得ている．なお，今回用いている比例電 磁弁の特性として，図 5 に示すような $0.25 \mathrm{~V}$ 付近 での入力電圧不感帶を有している。その結果, 図 4(a) 江定常偏差が現机てしまっている.

\section{3. 予見スライディングモード制御の}

構成

制御対象として，以下のような状態方程式，出力方 程式で表されるシステムを考える.

$$
x(k+1)=A x(k)+B u(k)
$$

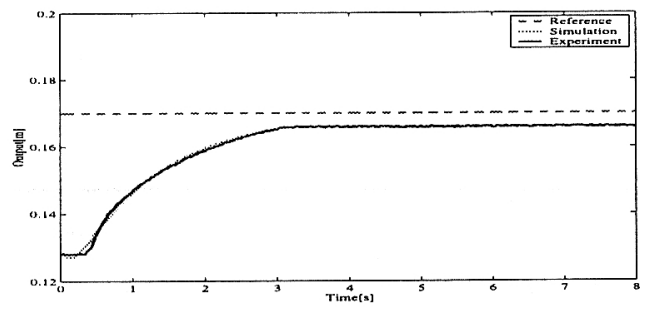

(a) Output

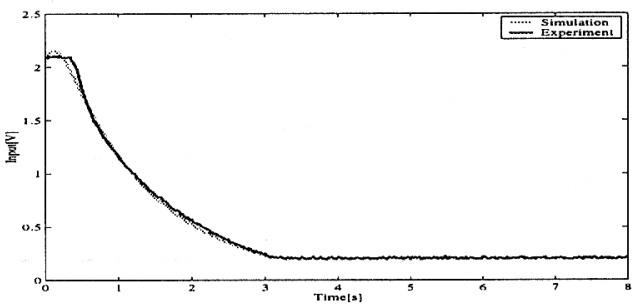

(b) Input

Fig. 4 Step response of thigh

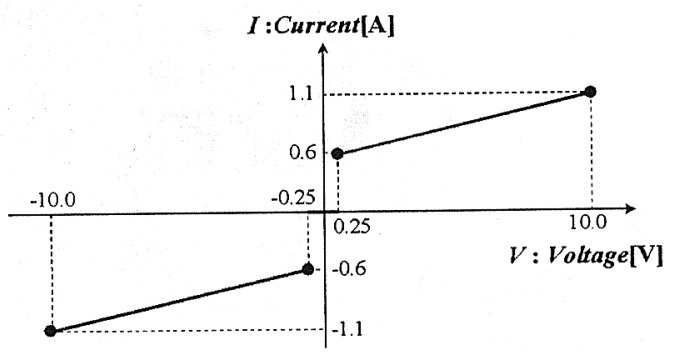

Fig. 5 Dead zone of valve 


$$
y(k)=C x(k) \cdots \cdots \cdots \cdots \cdots \cdots \cdots \cdots \cdots \cdots \cdots \cdots \cdots \cdots \cdots \cdots \cdots \cdots \cdots \cdots
$$

また, 誤差信号を式( 3 )のように定義する.

$$
e(k)=R(k)-y(k)
$$

ただし，

$$
\begin{aligned}
& x(k): \text { 状態変数ベクトル }(n \times 1) \\
& y(k): \text { 出力変数ベクトル }(m \times 1) \\
& u(k): \text { 入力変数ベクトル }(r \times 1) \\
& R(k): \text { 目標值信号ベクトル }(m \times 1)
\end{aligned}
$$$$
A: n \times n, B: n \times r, C: m \times n
$$

式 $(2 \cdot a)$, 式 $(2 \cdot b)$ で表される系は可制御, 可観測と する. 1 形最適サーボ系を構成するため, 式(4)のよ うな拡大系で表す。なお， $\Delta$ は 1 階差分を示す記号で ある。

$$
\begin{aligned}
& {\left[\begin{array}{c}
e(k+1) \\
\Delta x(k+1)
\end{array}\right]=\left[\begin{array}{cc}
I & -C A \\
0 & A
\end{array}\right]\left[\begin{array}{c}
e(k) \\
\Delta x(k)
\end{array}\right]} \\
& +\left[\begin{array}{c}
-C B \\
B
\end{array}\right] \Delta u(k)+\left[\begin{array}{l}
I \\
0
\end{array}\right] \Delta R(k+1) \\
& \quad \cdots \cdots(4 \cdot \mathrm{a})
\end{aligned}
$$

または

$$
X_{0}(k+1)=\Phi X_{0}(k)+\Gamma \Delta u(k)+\Gamma_{R} \Delta R(k+1)
$$

ここで， $M_{R}$ ステップ未来までの目標值が既知である とし，次のような未来目標值信号をその中に含んだ拡 大系を構成する(5)(6).

$$
\left[\begin{array}{c}
X_{0}(k+1) \\
X_{R}(k+1)
\end{array}\right]=\left[\begin{array}{cc}
\Phi & \Gamma_{P R} \\
0 & A_{R}
\end{array}\right]\left[\begin{array}{c}
X_{0}(k) \\
X_{R}(k)
\end{array}\right]+\left[\begin{array}{l}
\Gamma \\
0
\end{array}\right] \Delta u(k)
$$

または、

$$
\bar{X}_{0}(k+1)=\bar{\Phi} \bar{X}_{0}(k)+\bar{\Gamma} \Delta u(k)
$$
ただし，

$$
\begin{aligned}
& X_{R}(k)=\left[\begin{array}{c}
\Delta R(k+1) \\
\Delta R(k+2) \\
\vdots \\
\Delta R\left(k+M_{r}\right)
\end{array}\right] \\
& \Gamma_{P R}=\left[\begin{array}{llll}
\Gamma_{R} & 0 & \cdots & 0
\end{array}\right] \\
& A_{R}=\left[\begin{array}{ccccc}
0 & I_{m} & 0 & \cdots & 0 \\
\vdots & \ddots & \ddots & \ddots & \vdots \\
\vdots & & \ddots & \ddots & 0 \\
\vdots & & & \ddots & I_{m} \\
0 & \cdots & \cdots & \cdots & 0
\end{array}\right]
\end{aligned}
$$

ここで, 式 $(5)$ を安定に制御するような制御入力を求 めるために, 最適レギュレータ理論を適用する。そこ で、次のような二次形式評価関数を定義する。

$$
J=\sum_{k=-M_{k+1}}^{\infty}\left[\left[X_{0}^{T}(k) X_{R}^{T}(k)\right]\left[\begin{array}{cc}
Q & 0 \\
0 & 0
\end{array}\right]\left[\begin{array}{c}
X_{0}(k) \\
X_{R}(k)
\end{array}\right]\right.
$$

$$
\left.+\Delta u^{T}(k) H \Delta u(k)\right]
$$

ただし，QQ正定行列あるいは半正定行列 $\{\boldsymbol{Q}=$ $\left(\boldsymbol{Q}^{1 / 2}\right)^{T} \boldsymbol{Q}^{1 / 2}$ と書いたとき $\left(\boldsymbol{Q}^{1 / 2}, \boldsymbol{\Phi}\right)$ は可観測 $\}, \boldsymbol{H}$ は 正定行列である.

これより, 全系が安定化できることにより誤差変数 $\boldsymbol{e}(k)$ が $k \rightarrow \infty$ で $\boldsymbol{e} \rightarrow 0$ となるので, 目標值との誤差な く収束することができる。この式 $(7)$ を最小とするよ うな制御入力は以下のように与えられる.

$$
\begin{aligned}
& \Delta u(k)=\bar{F} \bar{X}_{0}(k) \\
& \quad=F_{0} X_{0}(k)+\sum_{j=0}^{M_{R}} F_{R}(j) \Delta R(k+j)
\end{aligned}
$$

ただし，

$$
\begin{aligned}
& \bar{F}=\left[\begin{array}{ll}
F_{0} & F_{R}
\end{array}\right] \\
& F_{0}=-\left[H+\Gamma^{T} P \Gamma\right]^{-1} \Gamma^{T} P \Phi \\
& F_{R}(0)=0 \\
& F_{R}(j)=-[H+\Gamma P \Gamma]^{-1} \Gamma^{T}\left(\xi^{T}\right)^{j-1} P \Gamma_{R} \quad(j \geq 1) \\
& \xi=\left[I-\Gamma\left[H+\Gamma^{T} P \Gamma\right]^{-1} \Gamma^{T} P\right] \Phi \\
& P=Q+\Phi^{T} P \Phi-\Phi^{T} P \Gamma\left[H+\Gamma^{T} P \Gamma\right]^{-1} \Gamma^{T} P \Phi
\end{aligned}
$$

次に, スライディングモードサーボ系を予見スライ ディングモードサーボ系へと拡張する.手順はスライ ディングモード制御器および超平面を設計し, 状態量 $\overline{\boldsymbol{X}}_{0}(k)$ を零にするようなレギュレータ問題として考 え, それを実現可能とする制御入力 $\boldsymbol{u}(k)$ を求める. ここで

$$
\bar{\sigma}(k)=\bar{S} \bar{X}_{0}(k), \bar{S} \bar{\Gamma}>0
$$

となる切換関数を考える.ここでスライディングモー ド制御の入力として二つの独立した項から構成される 入力を式(11) と定義する.

$$
\Delta u(k)=\Delta u_{e q}(k)+\Delta u_{n l}(k)
$$

ただし，ここでの $\Delta \boldsymbol{u}_{e q}(k)$ はスライディングモード制 御の超平面に拘束するための入力であり, $\Delta \boldsymbol{u}_{n l}(k)$ は スライディングモード領域にない状態から, 領域内に 到達させるための入力である.これらの制御入力を式 (12), 式(13)のように定義する(7).

$$
\begin{aligned}
& \Delta u_{e a}(k)=-(\bar{S} \bar{\Gamma})^{-1} \bar{S}(\bar{\Phi}-I) \bar{X}_{0}(k) \\
& \Delta u_{n l}(k)=-\eta(\bar{S} \bar{\Gamma})^{-1} \bar{\sigma}(k) \ldots \ldots \ldots \ldots . . .
\end{aligned}
$$

なお， $\eta$ は $0<\eta<2$ の範囲であれば漸近安定となり, $0<\eta<10$ 範囲であればチャタリングのないスライデ イングモード制御ができることが知られている(7).こ こで, 切換超平面を $\overline{\boldsymbol{S}}$ の代わりに式 $(8)$ に示す最適 サーボ系のフィードバック係数 $\overline{\boldsymbol{F}}$ を用いることで $\boldsymbol{u}_{e q}(k)$ と $\boldsymbol{u}_{n l}(k)$ がそれぞれ式(14)，(15)として成り 立つ.

$$
\Delta u_{e q}(k)=-(\bar{S} \bar{\Gamma})^{-1} \bar{S}(\bar{\Phi}-I) \bar{X}_{0}(k)
$$




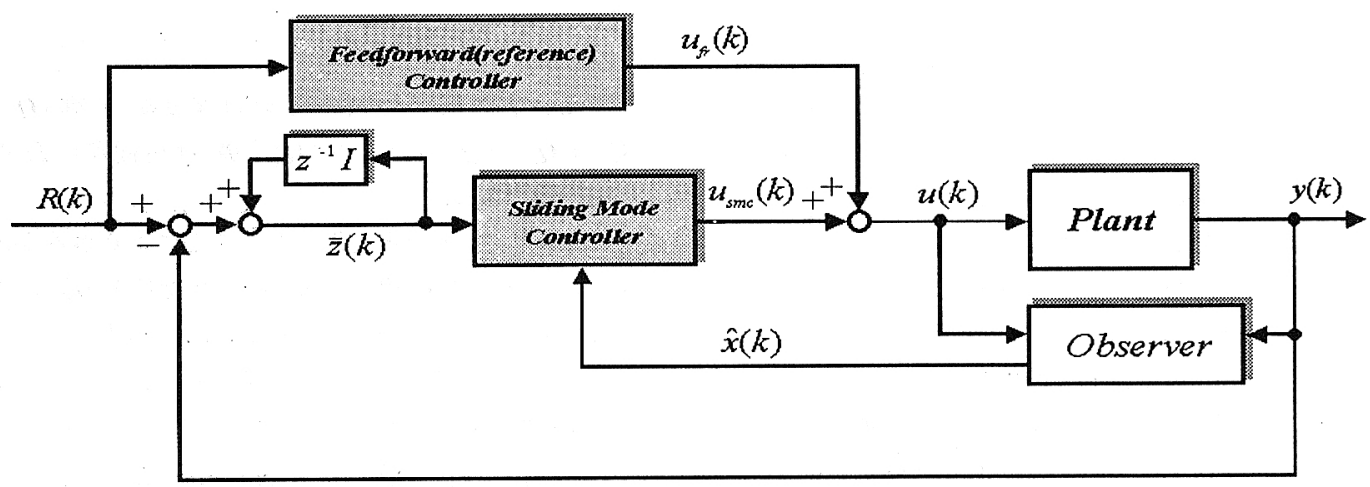

Fig. 6 Block diagram of Preview Sliding Mode Control (PSMC)

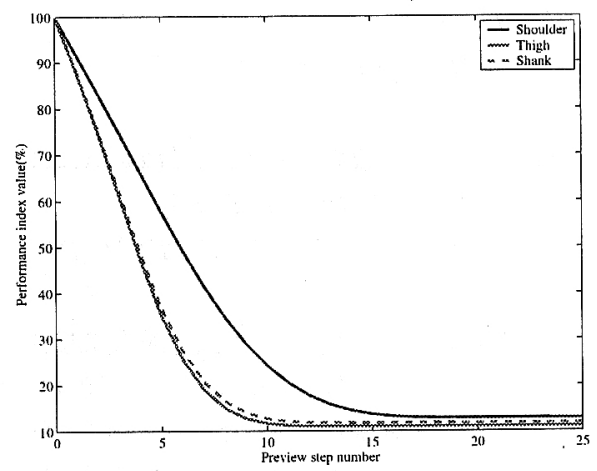

Fig. 7 Performance index value

$$
\begin{aligned}
& \quad=-\left(F_{0} \Gamma\right)^{-1}\left[F_{0}(\Phi-I) X_{0}(k)\right. \\
& +\left[F_{0} \Gamma_{R}-F_{R}(1)\right] \Delta R(k+1) \\
& \left.\quad+\sum_{j=2}^{M_{R}}\left[F_{R}(j-1)-F_{R}(j)\right] \Delta R(k+j)\right] \cdots \cdots(14) \\
& \Delta u_{n \ell}(k)=-\eta(\bar{S} \bar{\Gamma})^{-1} \bar{\sigma}(k) \\
& \quad=-\eta\left(F_{0} \Gamma\right)^{-1}\left[F_{0} X_{0}(k)+\sum_{j=1}^{M_{R}} F_{R}(j) \Delta R(k+j)\right]
\end{aligned}
$$

式(14)，(15)より予見スライディングモード制御の 入力は以下のように表される.

$$
\Delta u(k)=\Delta u_{s m c}(k)+\Delta u_{f r}(k)
$$
ただし

$$
\begin{array}{r}
\Delta u_{s m c}(k)=-\left(F_{0} \Gamma\right)^{-1}\left[F_{0}(\Phi-I)+\eta F_{0}\right] X_{0}(k) \\
\cdots \cdots \cdots \cdots \cdots \cdots(1) \\
\Delta u_{f r}(k)=-\left(F_{0} \Gamma\right)^{-1}\left[F_{0} \Gamma_{R} \Delta R(k+1)\right. \\
\left.+\sum_{j=1}^{M_{R}}\left[F_{R}(j-1)-(1-\eta) F_{R}(j)\right] \Delta R(k+j)\right]
\end{array}
$$

\begin{tabular}{|c|c|c|}
\hline & \multicolumn{2}{|r|}{ Shoulder } \\
\hline SMC & \multicolumn{2}{|c|}{$\begin{array}{c}Q=\operatorname{diag}[200 \quad 10 \quad 10 \quad 100] \\
H=0.4, \quad \eta=0.2\end{array}$} \\
\hline Observer & $L=$ & $\left.\begin{array}{c}-1.0057 \\
7.4849 \times 10^{-3} \\
-7.9884 \times 10^{-5} \\
3.9912 \times 10^{-4}\end{array}\right]$ \\
\hline & \multicolumn{2}{|c|}{ Thigh } \\
\hline SMC & \multicolumn{2}{|c|}{ 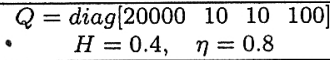 } \\
\hline Observer & $L=$ & $\left.\begin{array}{c}-1.0012 \\
1.1015 \times 10^{-2} \\
-2.5096 \times 10^{-5} \\
1.2787 \times 10^{-4}\end{array}\right]$ \\
\hline & \multicolumn{2}{|r|}{ Shank } \\
\hline SMC & \multicolumn{2}{|c|}{ 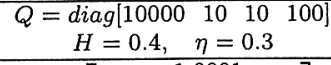 } \\
\hline Observer & $L=$ & $\left.\begin{array}{c}-1.0001 \\
7.0988 \times 10^{-4} \\
-1.7545 \times 10^{-7} \\
1.3818 \times 10^{-6}\end{array}\right]$ \\
\hline
\end{tabular}

式(16)で表される第 1 項は式(17)のように表される スライディングモード制御入力, 第 2 項は式(18)のよ うに表される未来目標値を用いた予見フィードフォワ
Table 3 Design parameters of PSMC

ード制御入力である.したがって，予見スライディン グモードサーボ系の構成は図 6 に示すようになる。な お，制御器を実機に実装する場合においては状態量の 観測が行えないため，オブザーバを用いた状態推定を 行っており，本研究では同一次元オブザーバを適用し ている。

$$
\text { 4. シミュレーション }
$$

図 5 の不感帯を有している本制御対象に対し, シミ ュレーションにて本研究手法が有効であることを実証 する.ここで，予見ステップ数については式(7)を解 析的に求め, 図 7 に示すように横軸に予見ステップ数 を示し，縦軸に予見ステップ数が零の場合に対する評 価関数值の割合を示している。これより予見補償によ り評価関数值が大幅に低減することがわかる。なお， 図 7 より各関節ともに評価関数値が最も小さい予見ス 
テップ数 $M_{R}=15$ として設計した。 これは実機に実装 する際に予見ステップ数を同一にすることで，プログ ラムの記述が簡略化できるためである。また，用いた 各関節における重み行列 $\boldsymbol{Q}, \boldsymbol{H}$ ，そしてオブザーバゲ イン Lはそれぞれ表 3 のように設計しており, 演算 時間は計算機の演算処理速度を考慮し, 目標値を求め るための逆運動学の計算, 制御入力の演算等を合わせ て $50 \mathrm{~ms}$ として計算している.クの設計においては， 值を大きく設定してしまうと制御入力のチャタリング が起こってしまうだけでなく，高圧下で使用される油 圧駆動システムでは, 機器の破損や突発的なサージ圧 を引き起こす原因となるほかに, 制御対象をモデル化 する際に無視した高周波域を励振し，スピルオーバな どの発振を引き起こす可能性があり，非常に危険とな る.しかし， $\eta$ の值を極力低く設定してしまうとスう イディングの動作が遅くなり，スライディングモード のロバスト性が失われてしまう。よって, 実験による 試行錯誤の末に設計している.この設計值も表 3 に示 す.

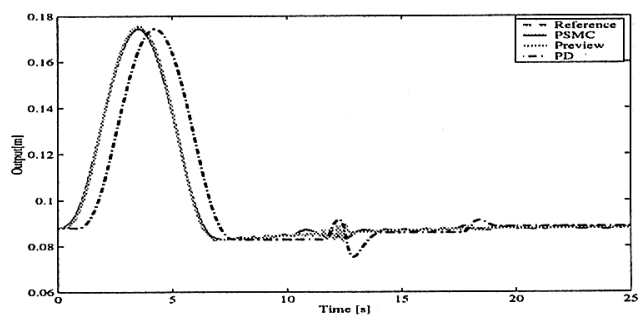

(a) Output

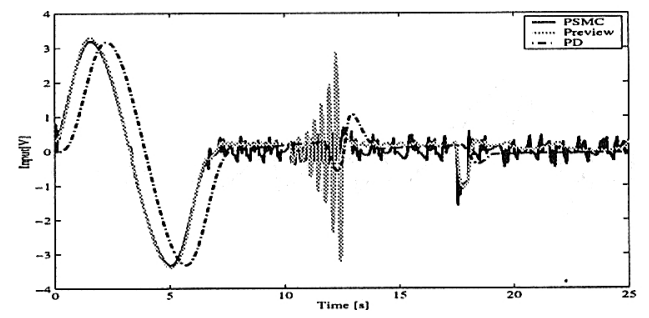

(b) Input

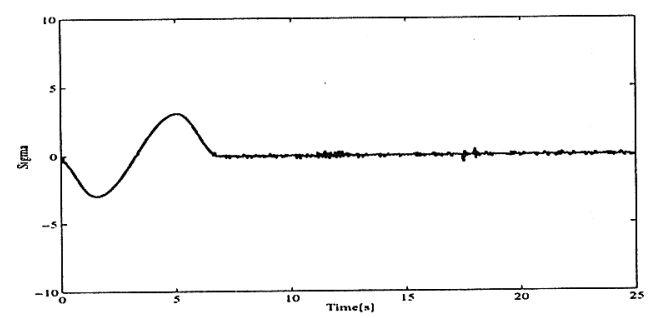

(c) Sigma

Fig. 8 Simulation results of thigh (leg 1)
シミュレーションを行うにあたり，実際は各関節の 支持脚時にパラメータ変動や外乱入力が起こると考光 られることから，10〜 $12.5 \mathrm{~s}$ にパラメータ変動させ， 17.5〜18 s でステップ外乱を与えている. その時の左 前脚 (leg 1)の腿関節のようすを図 8 に示す.この結 果より予見スライディングモード制御は離散時間系の ために純粋なスライディングモードにはならず, 準ス ライディングモードを生じるためにパラメータ変動や 外乱入力に刘しわずかに影響を受けるものの，各関節 ともに PD 制御に比べ，応答性能の良さが表れている のが見受けられる。ただし，PDゲイン(比例ゲイン $K_{p}$ ，速度ゲイン $\left.K_{d}\right)$ 峂 9〜11 に示す。また，予見制 御と比較すると，予見制御はパラメータ変動に対し， 応答性が予見スライディングモード制御に比べて振動 的になっており，その時に大きな制御入力が印加され ているのがわかる。よって本制御対象に対し，予見ス ライディングモード制御が有効であるといえる。

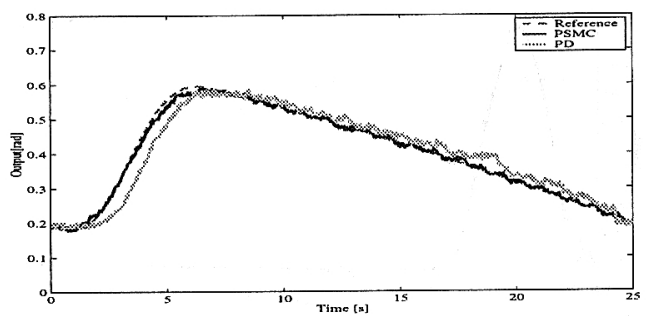

(a) Output

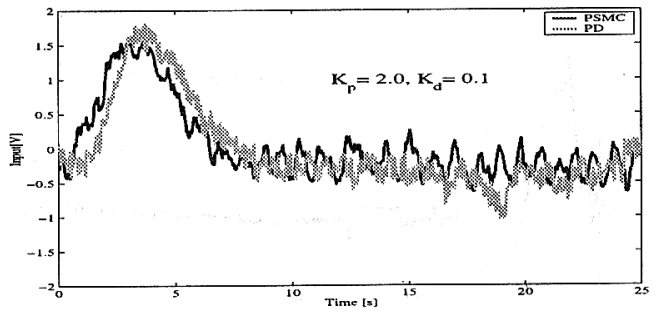

(b) Input

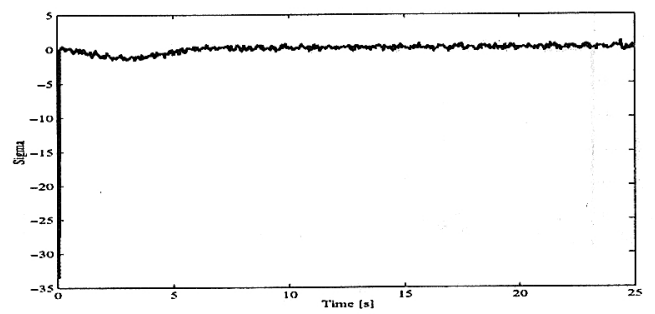

(c) Sigma

Fig. 9 Experimental results of shoulder (leg 1) 


\section{5. 歩 行 実 験}

本手法の有効性を, COMET-III $の$ 四脚歩行 (Tetrapod）で歩行させたときの奏験により検証する。なお， 設計值は表 3 を用いている.

まず, 図 9〜11 に歩行 1 周期 $25 \mathrm{~s}$ の各関節における 出力值と入力值，それにスライディングモードの切換 関数を示す。なお，比較対象のために従来の制御手法 であった PD制御も示している。実際には予見スライ ディングモード制御が離散時間系のために純粋なスラ イディングモードにはならず, 準スライディングモー ドを生じるために外乱等に対しわずかに影響を受ける ことがあるが, 結果より, 予見スライディングモード 制御は PD 制御に比べ位相特性が大幅に改善され, 追 従性能が増しているがわかる。しかし，図 $10(\mathrm{a}) の$ 6〜9s 付近では追従性の劣化が生じている。これはプ ラントへの制御入力が小さいことから, 図 5 に示した 不感帯の影響が大きく現れているのが原因と考えられ る.この問題の解決法として, サンプル目標値間隔を

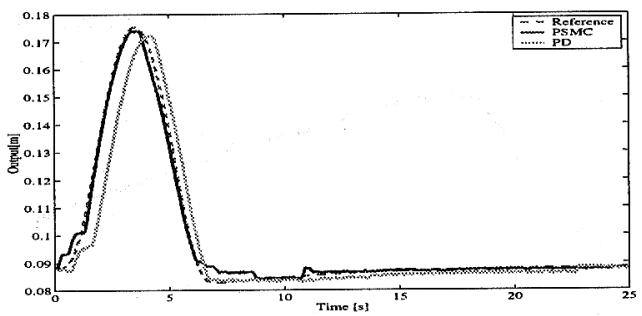

(a) Output

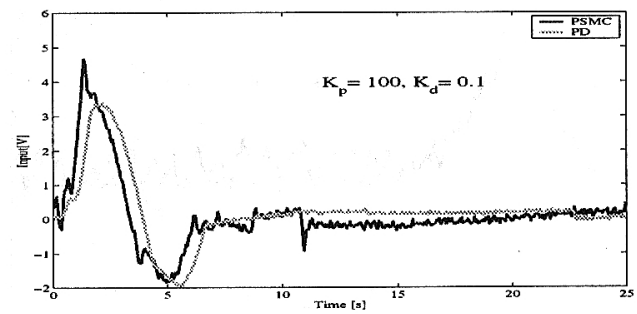

(b) Input

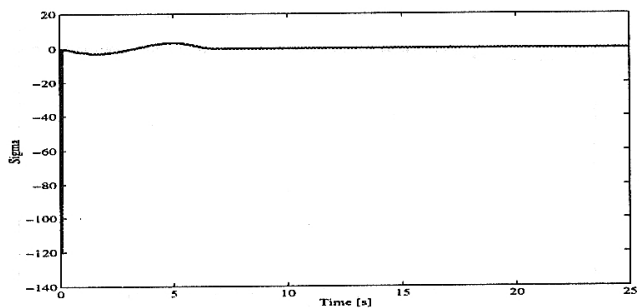

(c) Sigma

Fig. 10 Experimental results of thigh (leg 1)
大きく取れば制御入力が大きくなることから，この影 響はもう少し低減できると思われる。また, 図 9(c), 図 10(c), 図11(c) から, サンプル目標值間隔の大き い遊脚時の約 $0 \sim 8 \mathrm{~s}$ では支持脚時に比べ, 切換関数が 変化している。これは予見スライディングモード制御 の特徴としての切換面が目標值に先立ち変化するとい う特徵(6)'が示されている.

次に, 左後脚 (leg 3) の腿関節に同一の制御器を用い た結果を図 12 に示す。この結果から，2 章の仮定が有 効であると同時に，本制御器のロバスト性を示す結果 となっていることがわかる，なお，他の脚すべての関 節においても同様の結果が得られている.

次に, 実測による各関節の応答波形から脚機構の順 運動学に基づいて算出した左前脚 (leg 1)の先端が 1 周期に描いた軌道の結果と，目標值との絶対誤差を図 13 に示す。なお，座標系としては， $X$ 軸を進行方向, $Y$ 軸を水平方向, $Z$ 軸を鉛直方向の大地座標系と定 義している．同様に，比較対象として従来の制御法で ある $\mathrm{PD}$ 制御による軌道追従も示す。この結果からわ

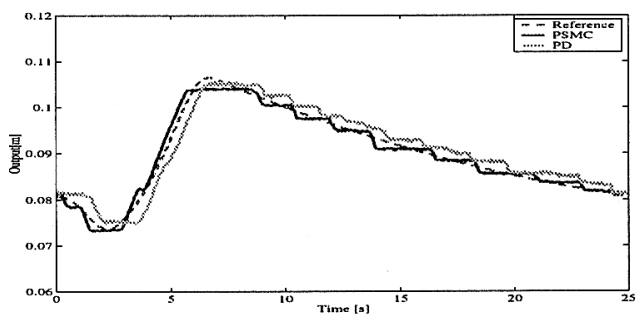

(a) Output

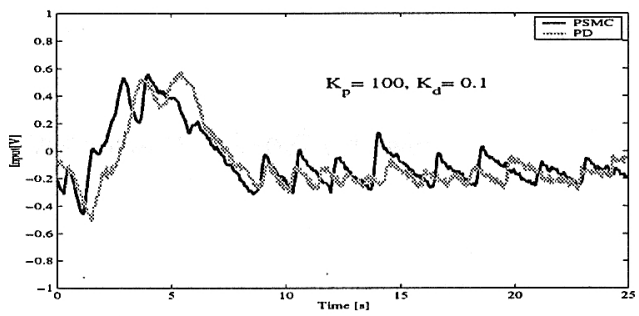

(b) Input

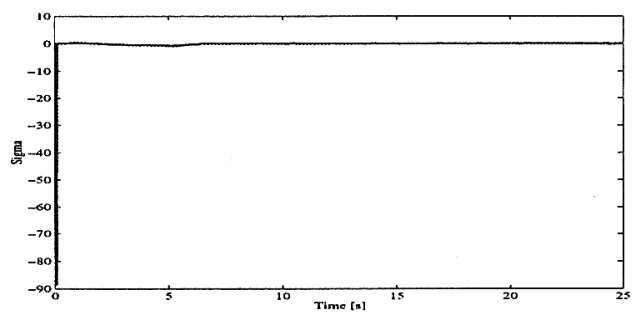

(c) Sigma

Fig. 11 Experimental results of shank (leg 1) 
かることは， $Y$ 軸の目標軌道は一定としており予見ス ライディングモード制御と PD 制御の違いがほとんど 見られないが， $X$ 軸， $Z$ 軸においては子見スライディ ングモード制御による位相特性の改善により正確な位 置決めを可能とし, 脚先の軌道の正確性が明らかとな つている. 特に PD 制御では脚先軌道と目標位置の誤 差が最大 $3.3 \mathrm{~cm}$ あることから, 危険な地雷原を歩行 させるには適切でないと考えられる，よって予見スラ イディングモード制御の有効性が示された結果となっ た.

\section{6. 結言}

本報では油圧駆動方式を採用した COMET-IIIを用 いて目標值から出力までの伝達関数を二次系に一次の Padé 近似を付加したものとして導出し，予見スライ ディングモード制御器を用いた歩行の有効性を従来の $\mathrm{PD}$ 制御器と実験により比較することにより検証し た.

$\mathrm{PD}$ 制御では，油圧システムがむだ時間やその他の

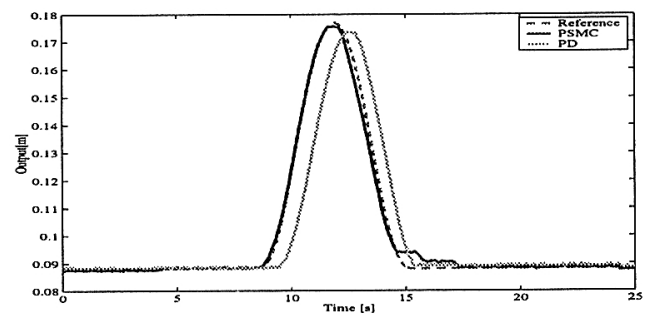

(a) Output

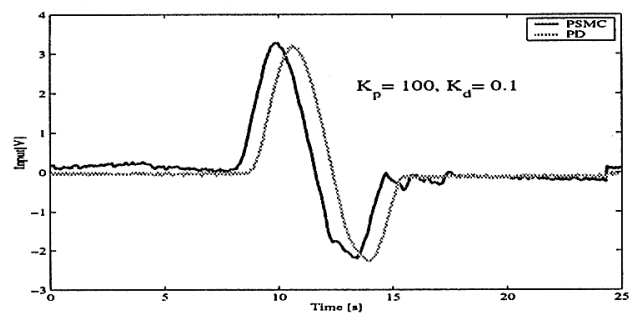

(b) Input

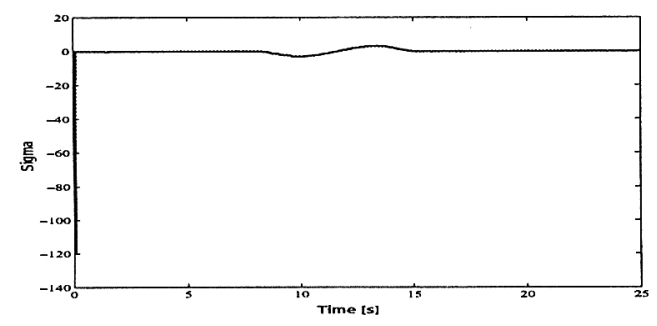

(c) Sigma

Fig. 12 Experimental results of thigh (leg 3)
非線形特性を有するために追従性の劣化が見られた が，本制御手法である予見スライディングモード制缻 ではスライディングモード制御によってパラメータ変 動に応じることなく, かつ, 予見フィードフォワード 補償により位相特性が大幅に改善され，良好な軌道追 従性能が得られた。本報では制御対象である COMET-IIIの支持脚時の数学モデルの検出は困難と 考え, 支持脚時は遊脚時のモデルをそのまま適応した が，実際には遊脚時と支持脚時ではモデルの違いは大

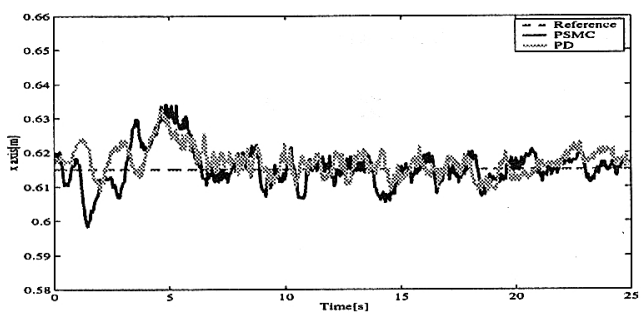

(a) $X$-axis

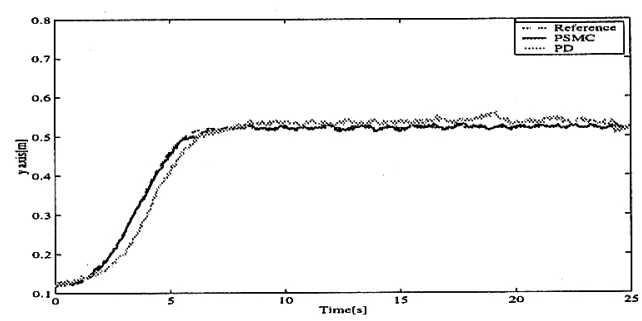

(b) $Y$-axis

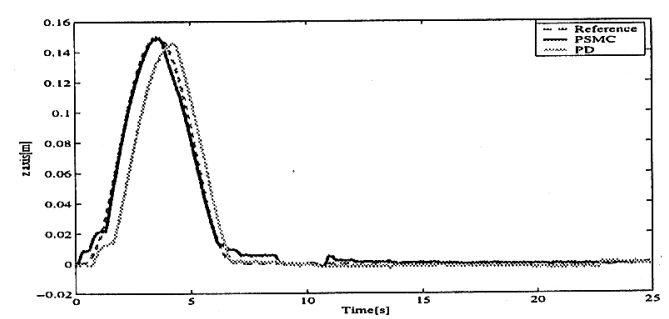

(c) $Z$-axis

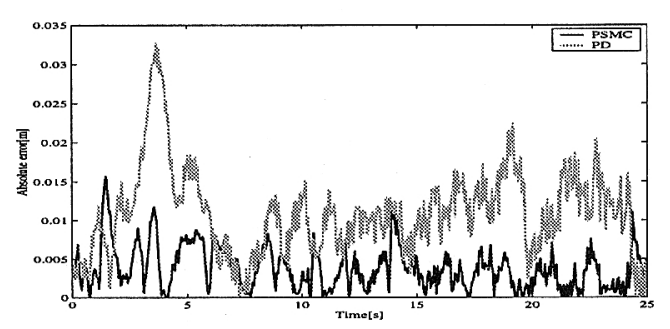

(d) Tracking error

Fig. 13 Experimental results of trajectory control (leg 1) 
きいと考えられる.よってさらなる性能の向上を考え るならば，支持脚時のモデルは遊脚時にかかる外乱と 考え，この外乱信号を予見制御系の中に組入れること により向上が見込まれる(5).また, 状態推定を行うに あたり同一次元線形オブザーバではなく非線形 VSS オブザーバを設計することにより，さらなるロバスト 化を図ることができると考えられる.

なお, COMET-IIIでは油圧駆動系において比例電 磁弁を使用しており，その影響で不感帯を有している ことから応答が振動的になっていたが, サーボ弁を用 いることでその問題を解決できると考えている.

\section{文献}

(1) Huang, Q.-J. and Nonami, K., Humanitarian mine detecting six-legged walking robot and hybrid neuro walking control with position/force control, J. Mcch.. 13 (2003), 773790 ).

(2) Nonami, K., ほか 7 名, Development of Mine Detection Robot COMET - III, JSME Int. J., Ser. C, $46-3$ (2003). 881890 .

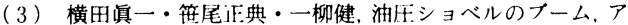
一ム系の高精度奇跡制御，機論，62-593、C (1996)，161 167.

（4）山田宏尚・武市教児・武藤高義、油压パワーショベルの スライディングモード制御, 機論, 68-670, C (2002), 146152.

（5） t:谷武上・江. H:iF：ディジタル予見制御，(1992)，産業図 書.

（6）佐藤匡・土行武f:・江：：汭：離散時間予見スライディン グモードサーボ系とその)特性. システム制御情報学会論 文誌, 1412 (2001), 582592

（7）野波健蔵・目宏奇，スライディングモード制御，(1994)。 コロナ社. 